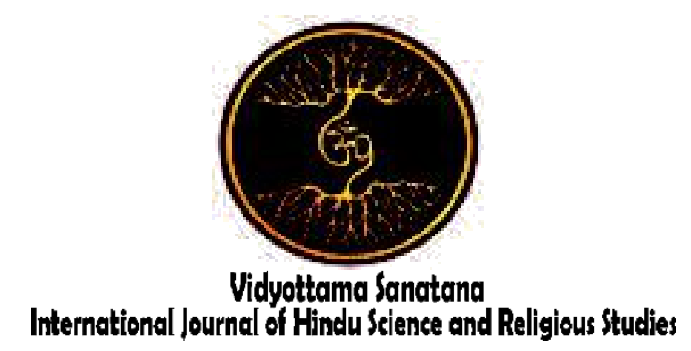

Vol. 3 No. 1 May 2019

\title{
SIWA-SISYA RELATIONSHIP ON NGABEN CEREMONY IN ADAT BELAYU VILLAGE
}

\author{
By: \\ I Wayan Wirta, Ida Bagus Putu Supradi \\ Institut Hindu Dharma Negeri Denpasar \\ E-mail :wirta@ihdn.ac.id
}

Received: Pebruary 2, 2019

Accepted: May 22, 2019

Published: May 31, 2019

\begin{abstract}
This research entitled: "Siwa-sisya Relationship at Ngaben Ceremony in Adat Village / Pakraman Belayu, Marga, Tabanan". Obsessed with fulfilling the curiosity of the practice of holding a ceremonial ceremony involving a siwa-sisya relationship. This siwa-sisya relationship still seems to be held in Belayu. Whereas in some other traditional villages in Bali the siwa-sisya relationship has begun to diminish. This means that this research requires the disclosure of facts behind the diversity of these siwa-sisya relationship. The research with the title of the siwa-sisya relationship on the Ngaben ceremony in Belayu, which was reviewed from the perspective of phenomenal communication, had never been examined by other researchers before, so it was open for being research. Thus there are three specific objectives to be achieved by this study, namely: to describe and interpret data regarding (1) the reality of the siwa-sisya relationship on the Ngaben ceremony in Belayu; (2) social construction of siwa-sisya relationship on the Ngaben ceremony in Belayu; and (3) communication management siwa-sisya relationship on the Ngaben ceremony in Belayu. This study uses qualitative research methods, while the data collection is done through observation, interviews, and document use. The collected data is analyzed by data reduction techniques, and data display, then conclusions or verification are drawn from both. The theoretical foundation used to interpret data is social exchange theory, social construction theory, and communication management theory. This study produced three findings, namely (1) the reality model of the siwa-sisya relationship on the Ngaben ceremony in Belayu; (2) the social construction model of the siwa-sisya relationship on the Ngaben ceremony in Belayu; (3) management model of student communication on the Ngaben ceremony in Belayu. These findings are at once the conclusions of this study.
\end{abstract}

Keywords: Relations, Students, Ngaben, Communication Phenomena. 


\section{Introduction}

The phenomenon of suka, duka, lara, pati cannot be separated from human life. In general there are two important events in human life, namely marriage and death. Both of them get attention by custom and religion. This can be observed in the lives of Hindus in Bali. This is referred to by Turner as an anthropological experience and is the basis of the theodies religious that exist in funeral rituals. (Atmaja, 2015: 2; Turner, 2012: 440).

The death ceremony in Bali is called Ngaben. Ngaben is an ancestral inheritance on how to complete the body. The implementation of Ngaben refers to the teachings of tattwa, susila, and acara, which are intended to help the process of returning the five mahabhuta elements to the body (micro cosmos / bhuwana alit), through burial or burning. And symbolically aims to deliver the spirit / atman to the nature of pitra . (Sudarsana, 2009: 5).

It is naturally true that the process of returning the five mahabhuta elements from the micro cosmos / bhuwana alit to the macro cosmos / bhuawa agung if left unchecked without Ngaben ceremony would have destroyed itself. But for Hindus in Bali, letting the decay process of the body occur naturally without the ceremony of cremation is contrary to the teachings of religion and tradition which have been carried out for generations (Pemayun, 2016: 10).

The foundation of the implementation of Ngaben if traced to the source of its teachings, can be referenced from the Book of Pancama Weda, Bhagawadgita, teaching Hindus to carry out sacrifices or yadnya. This is in accordance with the teachings of Bhagavadgita III.10:

"Saha-yajnah prajahsrtva purovaca prajapatih, anena prasavisyadhvam esa vo 'stv ista-kama-dhuk" which means "Once upon a time, Prajapati the Creator has created the universe and all its contents through yadnya or sacred offerings and said: prosperity all through this holy act. Carrying out acts as sacred offerings like this, will be able to fulfill everything you want "(Darmayasa, 2013: 282)
Based on the above verse, Ngaben is carried out based on the spirit of faith that aims to improve the welfare of ancestral spirits in the afterlife. With this Ngaben ceremony Hindus believe that the spirit ( atman ) that being Ngaben arrives and is received by Sanghyang Yamadipati, as the ruler of the pitra loka, and is placed in a place that is in accordance with his karmic devotion during his life in the world (Rai Putra (2014: 164).

The focus of this research lies in its formal object, namely social interaction in which it is loaded with elements of communication that build reality siwa-sisya relationship, social construction of siwasisya relationship and siwa-sisya communication management. While the material object is the Ngaben ceremony itself. The object of this study was observed through a phenomenal communication approach . This means that the phenomenon of the ceremonial ceremony is seen as an act of social, in which the process of communication between siswa. In this siwasisya relationship seen as the perpetrator (actor) of the Ngaben ceremony.

The choice of the Belayu Village as the location of the study is based on the assessment of unique characteristics. Based on the results of interviews with informants, it can be seen that the uniqueness includes: (1) the existing Belayu traditional village is the pengabih village of Puri Belayu with bhagawanta from Griya Gede Belayu which until now still maintains the principles of religious programs according to tattwa, susila, which have crystallized became the loka / dresta village version of the Belayu Traditional Village; (2) The Belayu version of the siwa-sisya system has been carried out evolutively for quite a long time; (3) In the midst of a renewal of Hindu thought about alternatives to implementing tabernacle outside the adat system that is not siwa-sisya oriented, the figures of the puri and griya, as well as the Belayu indigenous people still retain some important principles of implementing Ngaben in accordance with the principles agreed upon and has been 
implemented from the past until now; (4) The existence of thoughts or discourses so that the implementation of Ngaben in Belayu can be carried out effectively and efficiently in terms of time, energy, and costs, which may be considered, discussed and agreed upon by the traditional courtiers in the future provided that they do not sacrifice some principles that can reduce value spiritual / spiritual implementation of Ngaben .

There are three important issues that want to be disclosed (as well as the objectives) of this research, namely: (1) How do the realities siwa-sisya relationships on the Ngaben ceremony in the Village of Belayu? (2) What is the social construction of the siwa-sisya relationships on the Ngaben ceremony in the Belayu Traditional Village? (3) What is the management of student communication on the Ngaben ceremony in the Belayu Traditional Village?

Research is the process of learning to uncover the truth of a social reality by referring to scientific rules to gain experience as a scientist (Pujileksono, 2016: 15). Thus the results of this study are expected usefull theoretically, that contribute to the development of science communication Hindu as being established and developed in the Faculty of Dharma Duta IHDN Denpasar. And practically for students, lecturers, and other people who are interested in Hindu communication science studies . It can also be used by universities and / or religious institutions as references in organizing religious coaching or conducting studies in the same field.

\section{Methods}

The literature review is carried out on some of the results of previous relevant research, namely (1 ) Tary Puspa and
Subrahmaniam Saitya (201 5) who conducted a study entitled "The Existence of Walaka Gria in Ngaben Ceremony (Sisya Shiva Connections)" (2 ) Rica (2005), who conducted a study entitled " Changing the Pattern of Basic Relationships in Ethnic Hindu Communities Bali-Lombok " ; (3) Pande Putu Toya Wisuda with the Title " Ngaben Ceremony Amid the Social Change of the People in Bali (Case Study in the Krematorium of Santha Yana Peguyangan Kangin Village, North Denpasar District, Denpasar City) ". These three studies contributed many theoretical concepts and assumptions that were used as analysis material for the research problems.

In this study five concepts were used, namely (1) Relations ; (2) Siwa-sisya (3) Ngaben ceremony ; (4) Phenomenalogy of Communication (5) Adat Village / Pakraman.

In relation to this study, the relation of students to the Ngaben ceremony described is the knowledge and experience of the principals, namely siwa-sisya, when interacting and communicating in holding the Ngaben ceremony in Belayu. The theory used (1) Thibault and Kellay's Social Exchange Theory is coupled with Keith R. Legg's Patron Client Theory (2) The Theory of Social Reality Construction Peter Berger and Thomas Luckmann are combined with Schutz's Phenomenalogy theory (3) Communication Management Theory Michael Kaye is coupled with the theory Goffman Dramatic .

Based on the explanation of the theoretical foundation, the phenomenon of siwa-sisya relationship on the Ngaben ceremony studied can be described in a research framework or model, as follows. 
Figure 2.1

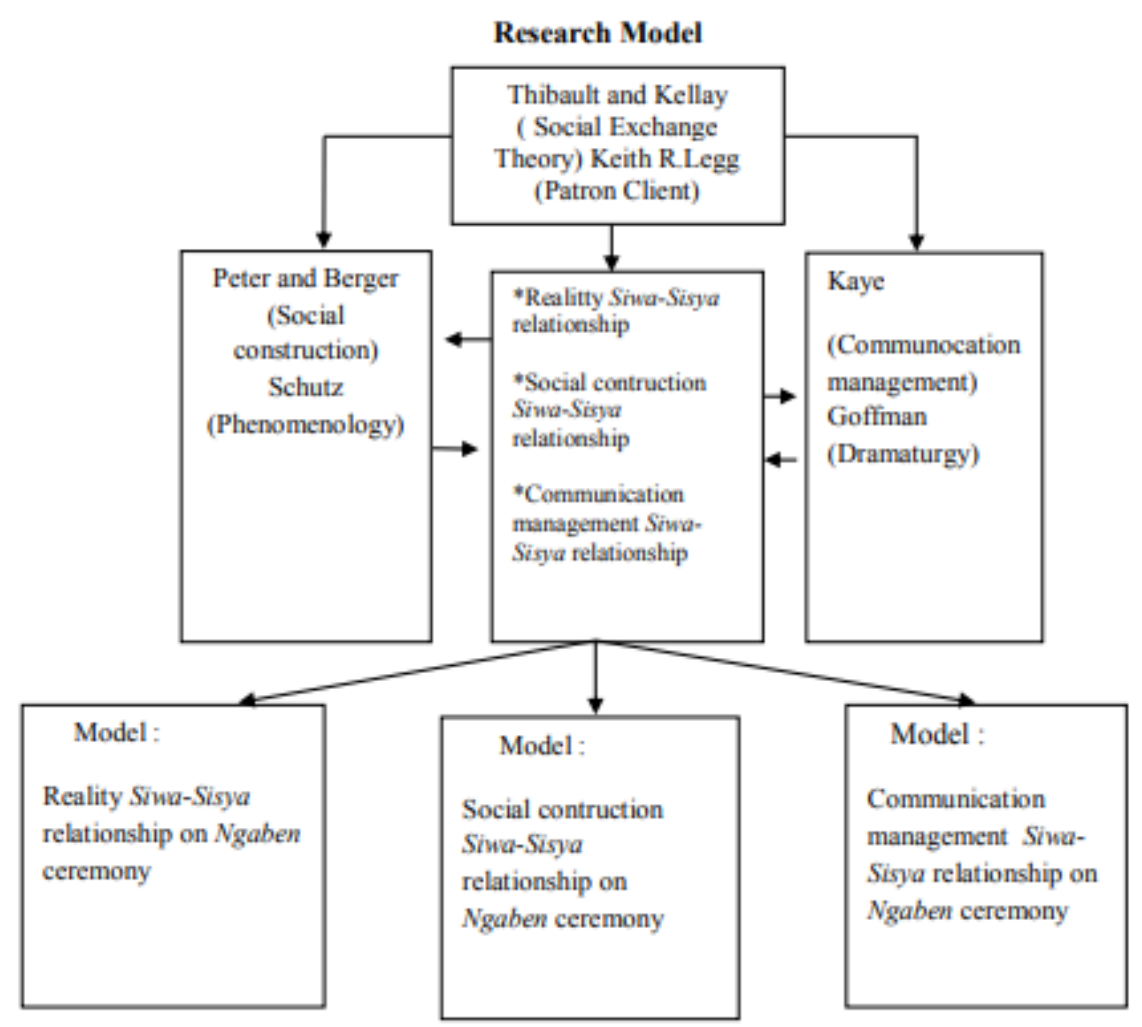

Regarding how this research is carried out in the field will be briefly described in terms of: types of research, location of research, types and sources of data, data collection techniques, data validity testing techniques, data analysis techniques, and data presentation techniques. This research paradigm positivistic, qualitative approach, aimed at the development of science, which is carried out in the field (arena). Classified as phenomenal communication research. While the location of the study was in Belayu Village, Marga District, Tabanan Regency.

\section{Results And Discussion}

This study succeeded in answering three research questions that have been formulated, namely: (1) What is the reality of the relationship Siwa-sisya on the Ngaben ceremony at Belayu ?; (2) How is the social construction of the student-student relationship / relationship on the Ngaben ceremony at Belayu ?; (3) What is the communication management of Siwa-sisya on the Ngaben ceremony in Belayu ? The answer is as follows.

\section{The Reality of Siwa-sisya Relationships on the Ngaben Ceremony in Belayu}

The reality of the Siwa-sisya relationship on the Ngaben ceremony in Belayu can be expressed based on facts about: (1) a history of the existence of a Siwa-sisya relationship on the Ngaben ceremony in Belayu; (2) characteristics / characteristics of the Siwa-sisya relationship on the Ngaben ceremony in Belayu; (3) community perceptions of student relations on the Ngaben ceremony in Belayu.

Regarding the history of the relationship of students to the Ngaben ceremony in Belayu it is said to have characteristic relationships that are formed based on the role of Belayu's King who wants the relationship between the king and Bhagawanta with his people as the relationship between the kaula kalawan gusti. 
The characteristics of the Siwa-sisya relationship on the Ngaben ceremony in Belayu can be classified based on the nature of the relationship, namely: (1) the existence of interdependent relationships; (2) the existence of mutually pleasant relationships; (3) there is a mutually beneficial relationship. This is consistent with the thinking of Scott (1972) and Keith R. Legg (1983) which implies several basic indicators for the continuation of patron-client relations, namely; (1) there is a valuable gift that allows the other party to see the need to maintain that relationship. The gift can be in the form of goods or services in various forms; (2) the recipient feels they have an obligation to reciprocate so that there is a mutual relationship (principle of recepperity). In this case it can be reaffirmed that patron-client relations do not contain coercion dimensions or due to the existence of formal authority.

Public perceptions of the student relationship on the Ngaben ceremony can be seen from the results of interviews with 20 informants whose answers were grouped, obtained three categories of informant perceptions, namely: (1) as a sacred relationship; (2) as a traditional relationship; (3) as a functional relationship. Based on the discussion above, it can be illustrated schematically the reality model of student relations on the Ngaben ceremony in Belayu.

Figure 3.1

Reality Siwa-sisya Relationship on Ngaben Ceremony Model

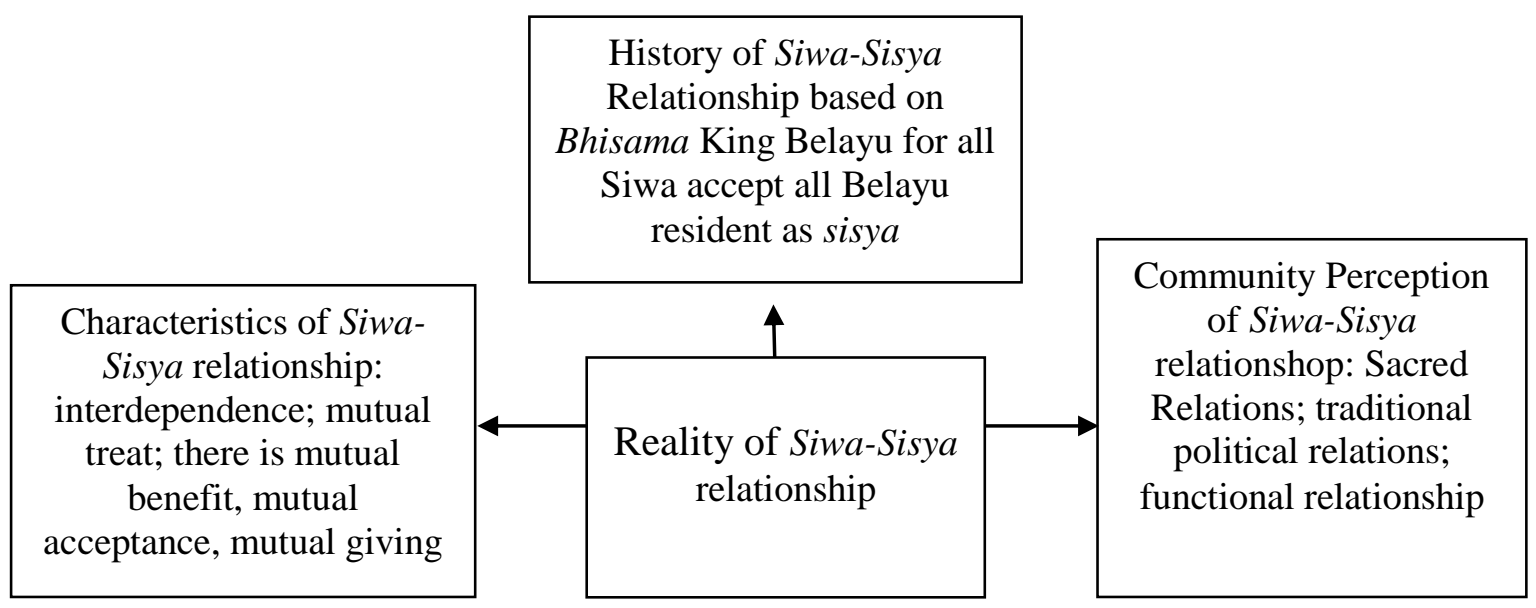

The reality of the siwa-sisya relationship on the Ngaben ceremony in Belayu can be concluded as a reality model of the siwa-sisya relationship formed historically based on the bhisama King Belayu which at that time (ancient times) ordered all the people to mesiwa to the bhagawanta namely Ida Pedanda Griya Gede Belayu . These siwa-sisya relationship are characterized by interdependence, mutual treat, and mutual benefit. These siwa-sisya relationship are also perceived by society today as sacred relationships, traditional political relationships, and functional relationships.
2. Social Construction of Siwa-sisya Relationship on the Ngaben Ceremony in Belayu

The social construction of student relations on the Ngaben ceremony in Belayu can be disclosed based on field data about: (1) siwa-sisya relationship on the Ngaben ceremony oriented to the past; (2) siwa-sisya relationship at present-oriented Ngaben ceremonies; (3) siwa-sisya relationship at future-oriented Ngaben ceremonies. The description of the data is as follows.

First, regarding the siwa-sisya relationship in the past is characterized by the characteristic motives of causes or motives. The motive of cause / because it 
can be explained that the siwa-sisya relationship on the Ngaben ceremony because: (1) to all the provisions of the implementation of Ngaben to always be oriented towards past events; (2) wanted the basic principles of padewasan, tata-titi atiwa-tiwa, tata-titi mekinsan, tata-titi Ngaben, tata-titi nyekah, tata-titi nyegaragunung, tata-titi panilapatian lan ngelinggihang dewa hyang as the source written that young people can learn; (3) want a reaffirmation of siwa-sisya relationship on the Ngaben ceremony; (4) want customary institutions to accommodate the aspirations of krama adat that have not yet been stipulated in the awig-awig and traditional banjar perarem and immediately bring them to the meeting to find a way out; (5) want customary institutions to build a system of self-defense from the negative influences of external cultures that enter through the media or due to the inclusion of foreign cultures through tourism; (6) want the siwa-sisya relationship based on language ethics sor singgih, dress modestly politely; completeness of uparengga and bebantenan Ngaben arranged by sarati banten pengayah Sang Tapeni; the stage of the ceremony and the series of his efforts led by Sulinggih accompanied by Welaka Griya as his devotee; the rules in the awig-awig banjar adat refer to the ordinances established by ancient wiku-natha, which are not easily changed. Based on these characteristics, the identity of the old tradition of relations is given.

Second, regarding current-oriented student relations, it has the characteristics of the motives: (1) that the work of the Ngaben being carried out can be carried out smoothly and successfully; (2) in order to comply with the current customary rules. (3) in order to provide sufficient logistics for the complete uparengga and bebantenan Ngaben; (4) so that the stage of the ceremony and the series of its efforts led by sulinggih accompanied by welaka griya can be carried out according to literary provisions and customary provisions. Thus, a momentary identity relationship can be given because it has a momentary interest, after which it rarely carries out a student relationship for various reasons.

Third, regarding future siwa-sisya relationship, it is categorized based on motives. Motives for here are based on religious reasons and social reasons. The religious reason for sisya (sang madwe karya Ngaben) is to pay debts to the ancestors. Whereas social reasons to invite the participation of krama adat, relatives, friends to witness the sang lampus ceremonial, with hope in the future to be carried out based on the principle of efficiency in terms of time, effort and cost without sacrificing the value and nature of the ceremony.

Departing from two reasons, the students siwa-sisya relationship on the Ngaben ceremony, then three categories of motives are made, namely the motives of the causes that are oriented to the past, the motives of the agar, which are oriented to the present, and the motives for the futureoriented. These three categories of motives are in accordance with Shcutz's thinking which calls it an account (Scott, 1970, in Douglas, 1970: 89-119). In this connection Shcutz describes accounts that can be observed in a person's actions or student actions which are in siwa-sisya relationship on the Ngaben ceremony. According to Schutz, it is rather difficult to observe motives for one's actions in a certain way. It was proposed to make the historical phase, namely the past and the future, he called because motives are oriented to the motive phase in the past and in order motives that are oriented towards the motive phase in the future (Schutz, 1972: xx-xxi).

Second, siwa-sisya relationship on the Ngaben ceremony, which are oriented towards the present found based on encouragement to fulfill their current interests, namely to carry out the caring of their parents. In order to be able to be carried out as well as possible, then he establishes a student relationship. So the motive is contemporary, short-term interest in a particular moment, namely when the madwe 
karya carries out the ceremony. After that they are no longer related to siwa, maybe because of school reasons or work outside the area or other reasons.

Third: siwa-sisya motifs establishing relationships on the Ngaben ceremony, which are oriented towards the future are found based on the urge to be able to hold the Ngaben ceremony which is in accordance with literature, but efficient in terms of time, effort and cost. The development of the community in the future requires the efficient use of time, energy and costs. If not, he will make other choices available outside his traditional banjar, or maybe even see the efficiency offered by other religions. This challenge needs to be thought of by traditional leaders who want to maintain old ways that are not in accordance with the efficiency, efficiency and time. According to the collected data, there were 4 informants who stated that they established siwa-sisya relationship based on encouragement to achieve the principle of efficiency of time, effort and cost.
Starting from data about three motives that encourage siwa-sisya relationship on the Ngaben ceremony, it is found that three categories of siwa-sisya relationship on the Ngaben ceremony, namely: (1) old tradition relations; (2) contemporary relations; (3)) efficient relations.

The old tradition of relations is that student relations are based on the provisions of customary values and norms that have been implemented from a long time ago until now are still considered relevant because they are local wisdom. Contemporary relations are student relations which are based on momentary or present interests. Efficient relations are student relations which are based on the hope to be realized in the future, namely student cooperation which emphasizes the efficiency of time, energy and costs. For example, the Ngaben ceremony is held jointly between the siwa and sisya based on accurate planning that has been carefully calculated. Based on the above explanation, we can find a model of social construction of student relations on the Ngaben ceremony in Belayu.

Figure 3.2

The Model of Social Construction of Siwa-sisya relationship on the Ngaben Ceremony in Belayu

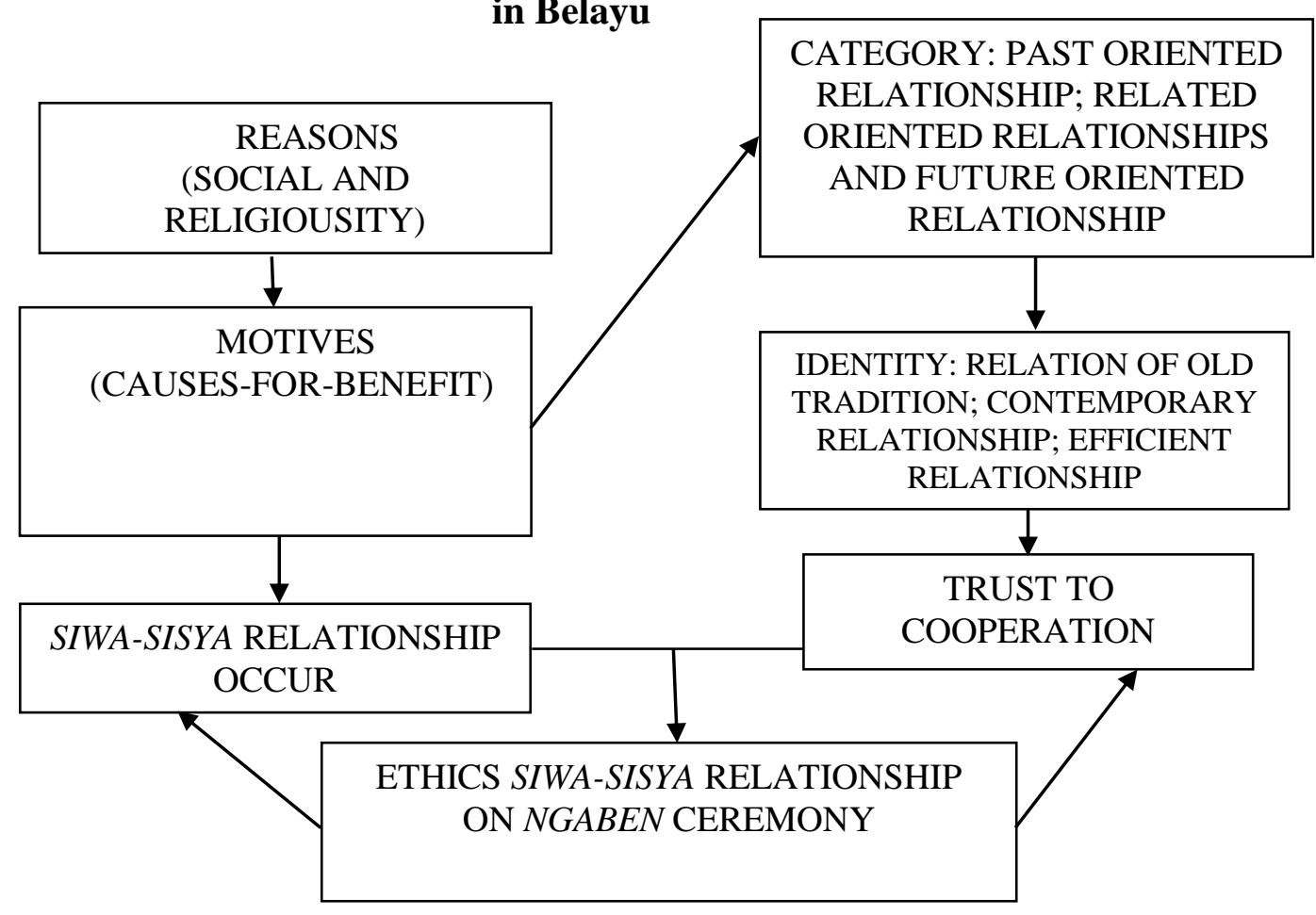


The social construction of siwa-sisya relationship on the Ngaben ceremony can be concluded as a social construction model of siwa-sisya relationship on the Ngaben ceremony which is constructed of three elements which are sequentially interrelated in terms of time, namely: (1) social reasons and religious motives that cause, so that it can be categorized as a relationship oriented to the past, and can be given the identity of an old tradition of relations. (2) elements of social and religious reasons that are motivated so that they can be categorized as relations that are oriented to the present, and can be given the identity of contemporary tradition relations. (3) elements of social and religious reasons that are motivated to, so that they can be categorized as futureoriented relations, and can be given an efficient identity of traditional relations. Establishment of siwa-sisya relationship on the ceremony based on the belief to work together to achieve a common goal, namely the success of the Ngaben ceremony.

\section{Siwa-Sisya Communication Management on the Ngaben Ceremony}

Field data that explains the management events of student communication on the Ngaben ceremony in Belayu include: (1) management of siwasisya impressions through verbal symbols; (2) managing the impression of students through nonverbal symbols; (3) competent student communication.

Furthermore, in this study, it will be seen that all activities of siwa or sisya as individuals in a situation of social interaction on the ceremony are called performance. Siwa or sisya performance in this case is his performance in front of the stage (front region or front stage) and his performance behind the stage (back region or back stage). The performance at the front of the stage is part of the performance of individuals who regularly function in general rules and remain to be defined by those who witness. In the performance in front of the stage there is a setting, for example when Sulinggih is there, there are Shiva Karana and the Upakara equipment needed. This setting tends to be more geographical, in this example that sulinggih cannot worship if it has not been supported by the situation in place. In addition, there are personal fronts such as clothing, gender, age, ethnicity, body size and shape, etc. that are needed by actors to complete the individual settings. Personal fronts are divided into two parts, namely appearance and manner.

The siwa-sisya relationship on the Ngaben ceremony is a series of activities through several stages and each stage there is a series, like a stage show. Siwa as an actor "manggalaning yadnya", his sisya as an actor "supporting yadnya". Siwa and sisya really wants to show an action or performance that is intended so that anyone who witnesses has an impression of what is displayed both by the student or his side. Therefore, either siwa or sisya prepares settings both geographically and personally.

In the context of communication management, Goffman's impression management concept emphasizes nonverbal communication, using nonverbal symbols, such as clothing, body movements, facial expressions, even in the context of performing rituals of Ngaben, there are various types of blessings, which function as spiritually activated yantra with spells and mudras. All of that can be categorized as a symbol of religious culture. However, based on the results of interviews with key informants and observations of student behavior when interacting with each other on the ceremony, verbal communication is also an important part of managing the impressions made by sisya.

Management of nonverbal impressions performed by students is more dominant than the management of verbal impressions. This is in accordance with Goffman's impression management thinking. The following is explained in more detail several nonverbal symbols managed by students in giving an impression on the implementation of the ceremony, which can be grouped: (1) 
tone of voice; (2) body gestures and gestures; (3) appearance; (4) facial expressions.

Competent student communication meant in this study is that student communication skills are related to the success of building cooperation with one another in order to achieve the goal of harvesting, namely the completion of uparangga and upakara / bebantanan Ngaben without shortages, and the implementation of upakara procedures from the beginning to end without a hitch. Facts about competency in student communication revealed are: (1) competent student communication; (2) competent communication.

In general, students show competence in communicating about the ins and outs of the implementation of Ngaben. Because if you are incompetent in holding a Ngaben ceremony, you will not achieve perfect results. Therefore, in some cases the holding of the Ngaben ceremony in Belayu, all matters relating to technical issues regarding the form, function, and meaning of banten Ngaben are only known and can be explained by siwa. Therefore, the role of the sisya becomes very dominant in providing direction and providing guidance in the procurement of food and beverage supplies.

On the other hand, those who are competent in communicating about the Ngaben ceremony are usually the prajuru adat who have experience involved in the implementation of harvesting in their traditional banjar, and have an interest in knowing everything, so they must be diligent in asking about what they do not know about form, function and the meaning of uparengga / banten is needed in certain ceremonies, depending on the level of quantity of the energy whether the level of uttama, madya or kanista. However, not all customary instructors who demonstrate competency communicate about the implementation of Ngaben.

Sometimes even though they have been involved in every Ngaben ceremony, but if their attentions are less curious, then their knowledge about the implementation of kebaben will never be complete, because there are many things that need to be understood, not only the form, but also the function and meaning. The management model of student communication on the Ngaben ceremony in Belayu can be described as follows.

Figure 3.3

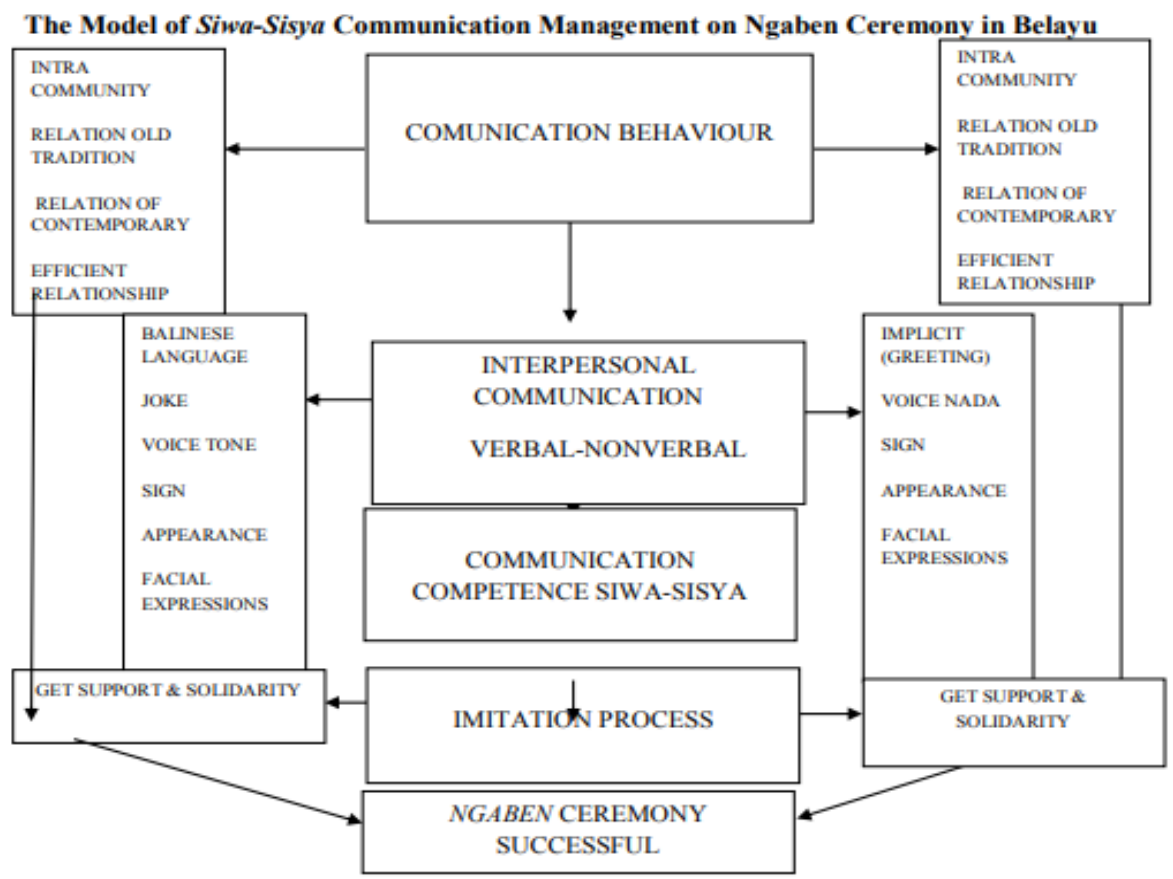


The management of siwa-siya communication on the Ngaben ceremony in Belayu can be concluded as a model that describes communication behavior that occurs between siwa and sisya on the Ngaben (intra-community) ceremony both in the category of past-oriented siwa-sisya relationship, with the identity of old tradition relations, and the categories of contemporary-oriented siwa-sisya relationship, with contemporary relations of identity and the categories of presentoriented siwa-sisya relationship, with efficient relations of identity, all communicating interpersonally through verbal and nonverbal symbols, and similar meanings. Thus both parties can be able to exchange information, knowledge and experience for the sake of implementing the Ngaben ceremony smoothly and successfully.

\section{Conclusion}

Research has produced three important findings, which are answers to the formulation of the problem posed. The three findings are also conclusions of the results of the research and discussion.

1. Findings about the Reality of siwa-sisya relationship on the Ngaben Ceremony in Belayu. The reality of the siwa-sisya relationship on the Ngaben ceremony in Belayu can be concluded as a reality model of the siwa-sisya relationship formed historically based on the bhisama King Belayu which at that time (ancient times) ordered all the people to mesiwa to bhagawanta namely Ida Pedanda Griya Gede Belayu . These siwa-sisya relationship are characterized by interdependence, mutual happiness, and mutual benefit. These siwa-sisya relationshipare also perceived by society today as sacred relationships, traditional political relationships, and functional relationships.

2. Findings about the Social Construction of siwa-sisya relationship on the Ngaben Ceremony in Belayu. The social construction of siwa-sisya relationship on the Ngaben ceremony can be concluded as a social construction model of siwasisya relationship on the Ngaben ceremony which is constructed of three elements which are sequentially interrelated in terms of time, namely: (1) social reasons and religious motives that cause, so that it can be categorized as a relationship oriented to the past, and can be given the identity of an old tradition of relations. (2) elements of social and religious reasons that are motivated so that they can be categorized as relations that are oriented to the present, and can be given the identity of contemporary tradition relations. (3) elements of social and religious reasons that are motivated to, so that they can be categorized as future-oriented relations, and can be given an efficient identity of traditional relations. Establishment of siwa-sisya relationship on the ceremony based on the belief to work together to achieve a common goal, namely the success of the Ngaben ceremony.

3. Findings about management of siwa-sisya communication on the Ngaben ceremony in Belayu. The management of siwa-sisya communication on the Ngaben ceremony in Belayu can be concluded as a model that describes communication behavior that occurs between siwa and sisya on the Ngaben (intra-community) ceremony both in the category of past-oriented siwa-sisya relationship, with the identity of old tradition relations, and the categories of contemporary-oriented siwa-sisya relationship, with contemporary relations of identity and the categories of present-oriented siwa-sisya relationship, with efficient relations of identity, all communicating interpersonally through verbal and nonverbal symbols, so that similarities occur. Thus both parties can exchange information, knowledge and experience for the sake of implementing the Ngaben ceremony smoothly and successfully. 
References

Atmaja, Nengah Bawa. 2015. "[Ngaben + Memukur $]=[$ Tubuh + Api $]+$ $[$ Uperengga + Mantra $]=[$ Dewa Pitara $=$ Sorga $]$ Perspektif Teori Sosial Ketubuhan Terhadap Kematian di Bali”. Denpasar: Pustaka Larasan.

Berger, Peter \& Thomas Luckman. 1975. "The Sosicial Construction of Reality, A Treatise in the Sociology of Knowledge. Australia: Penuin Book.

Darmayasa. 2013. Bhagavad Gita (Nyanyian Tuhan). Denpasar: Penerbit Yayasan Dharma Sthapanam

Kuswarno.2009. Metodologi Penelitian Komunikasi Penomenalogi, Konsepsi, Pedoman, dan Contoh Penelitiannya. Bandung : Widya.

Kaler, I Gusti Ketut. 2011. Ngaben Mengapa Manyat Dibakar?.Denpasar:Yayasan Dharma Naradha

Kuswarno.2009. Metodologi Penelitian Komunikasi Penomenalogi, Konsepsi, Pedoman, dan Contoh Penelitiannya. Bandung : Widya

MacMillan, J.H. dan Schumacher, S.2001. Research in Education: A.Conceptual Introduction (5th ed.). US.Longman Inc.

Moleong, Lexy J. .2006. Metodologi Penelitian kualitatif. Bandung: PT Rosdakarya

Muliono .1990. Kamus Besar bahasa Indonesia.Jakarta: Balai Pustaka.

Pemayun, Sri Bhagawan Putra Nata Nawa Wangsa. 2016.Upacara Ngaben.Denpasar: Pustaka Larasan

Pitana. I Gede,. 1996. Dinamika Masyarakat dan Kebudayaan Bali. Denpasar: Balipost

Pudja, Gde dan Tjokorda Rai Sudharta. 1975.

Manawadharmasastra, Kompodium Hukum Hindu,. Jakarta : PT Mayasari

Pujileksona. 2016. Metode Penelitian Komunikasi Kualitatif. Malang: Intrans Publishing
Rai Putra, Ida Bagus., Ida Bagus Jelantik, I Nyoman Argawa (ed). 2014. Swatikarana Pedoman Ajaran Hindu Dharma. Denpasar: Parisada Hindu Dharma Indonesia

Rica.2005.Perubahan Pola Hubungan Pasisyan pada Masyarakat Hindu Etnis bali-Lombok (Tesis S2).

Denpasar:Pascasarjana IHDN

Denpasar

Ritzer, George. 2005. Teori Sosial Postmodern (Muhammad Taufik Penerjemah). Yogyakarta:Kreasi Wacana.

Syaiful Rohim, 2009. Teori Komunikasi, Perspektif, Ragam, \& Aplikasi. Jakarta: Penerbit Rineka Cipta

Sudarsana, I. K. (2017). Interpretation Meaning of Ngaben for Krama Dadia Arya Kubontubuh Tirtha Sari Ulakan Village Karangasem District (Hindu Religious Education Perspective). Vidyottama Sanatana: International Journal of Hindu Science and Religious Studies, 1(1), 1-13.

Tary Puspa, Ida Ayu dan Ida Bagus Subramaniam Saitya. 2015. Eksistensi Walaka Gria Dalam Upacara Ngaben (Pertautan Siwa Sisya). Surabaya: Penerbit Paramita

Toya Wisuda, Pande Putu. 2018. Upacara Ngaben DiTengah Perubahan Sosial Masyarakat di Bali (Studi Kasus) di Krematorium Santhayana Desa Peguyangan Kangin Kecamatan Denpasar Utara Kota Denpasar, Desertasi (Tidak Dipublikasikan). Denpasar: Pascasarjana IHDN Denpasar

Turner, Briyan S..2012. Sosiolog: Sejarah, Teori dan Metodologi (terjemahan). Yogyakarta:Pustaka Pelajar

Wikarman, I Nyoman Singgin. 2002. Ngaben (Upacara dari Tingkat Sederhana Sampai Utama). Surabaya: Penerbit Paramita 